\title{
Nutrient Availability from Douglas Fir Bark in Response to Substrate pH
}

\author{
James E. Altland ${ }^{1,3}$
}

USDA-ARS, Application Technology Research Unit, Ohio Agricultural Research and Development Center, 208 Ag. Eng. Building, 1680 Madison Avenue, Wooster, OH 44691

\author{
M. Gabriela Buamscha ${ }^{2}$ \\ USDA Forest Service, 333 SW First Avenue, Portland, OR 97208-3623
}

Additional index words. Pseudotsuga menziesii, lime, calcium carbonate, calcium hydroxide

\begin{abstract}
Two studies were conducted to determine the influence of substrate pH on nutrient availability in Douglas fir bark. Douglas fir bark was amended with either calcium carbonate $\left(\mathrm{CaCO}_{3}\right)$ or calcium hydroxide $\left[\mathrm{Ca}(\mathrm{OH})_{2}\right]$ at 13 rates to generate substrates with low to high $\mathrm{pH}$. A nonamended control was also maintained. The substrates received no other fertilizer amendments. Substrates were filled into nursery containers $(2.8 \mathrm{~L})$ and maintained in a nursery setting with $1.2 \mathrm{~cm} \cdot \mathrm{d}^{-1}$ overhead irrigation. At 1 and 6 weeks after potting, four containers of each lime treatment were harvested to determine substrate $\mathrm{pH}$ and availability of 13 nutrients. Substrate solutions used for analysis were obtained with the saturated media extract method. Waterextractable phosphorus and DTPA-extractable boron, iron, copper, and aluminum decreased with increasing substrate $\mathrm{pH}$. Other nutrients were either nonresponsive to substrate $\mathrm{pH}$ or the observed response was deemed more likely caused by calcium competition on cation exchange sites.
\end{abstract}

Ornamental container crops in the Pacific Northwest are grown primarily in Douglas fir [Pseudotsuga menziesii (Mirbel) Franco] bark (DFB). Similar to pine (Pinus taeda L.) bark in the southeast United States, DFB comprises the highest portion of most nursery substrates $(60 \%$ to $80 \%$ of the substrate mix, pers. obser.). Chemical and physical properties of DFB, as they pertain to use in container substrates, have recently been documented by Buamscha et al. (2007b). They reported nonamended DFB to have low $\mathrm{pH}$ (3.7 to 4.4); little or no available nitrogen $(\mathrm{N})$; relatively high water-extractable phosphorus ( $\mathrm{P} ; 10$ to $28 \mathrm{mg} \cdot \mathrm{L}^{-1}$ ) and potassium (K; 78 to $\left.162 \mathrm{mg} \cdot \mathrm{L}^{-1}\right)$; low levels of calcium (Ca), magnesium $(\mathrm{Mg})$, and sulfur (S); and moderate levels of some micronutrients. In a separate study, Buamscha et al. (2007a) documented that DFB alone provides sufficient micronutrients for annual vinca [Catharanthus roseus (L.) G. Don 'Peppermint Cooler'] grown at low pH (4.5 to 5.5). Macronutrient and micronutrient availability

Received for publication 12 Sept. 2007. Accepted for publication 24 Oct. 2007.

Special thanks to the Oregon Association of Nurseries for funding this research and to Gilda Medina, Vyacheslav Dobryk, and Magdalena Zazirska for skillful technical assistance.

Mention of proprietary products or company is included for the reader's convenience and does not imply any endorsement or preferential treatment by USDA/ARS.

${ }^{1}$ Research Horticulturist.

${ }^{2}$ Western Nursery Specialist.

${ }^{3}$ To whom reprint requests should be addressed; e-mail James.Altland@ars.usda.gov may not be sufficient to support plant growth when substrate $\mathrm{pH}$ is higher. Altland (2006) reported reduced growth of japanese maple (Acer palmatum var. atropurpureum Thunb.), hydrangea [Hydrangea macrophylla Thunb. (Ex J.A. Murr.) Ser. 'Endless Summer'], and leucothoe [Leucothoe axillaris (Lam.) D. Don] caused by a $\mathrm{pH}$-induced reduction of available N, P, and micronutrients in DFB. Similar observations of reduced plant growth with high substrate $\mathrm{pH}$ have been reported for crops grown in pine bark (Wright and Hinsley, 1991).

Little is known empirically about how $\mathrm{pH}$ affects nutrient availability in DFB substrates. Lucas and Davis (1961) determined the relationship between $\mathrm{pH}$ and nutrient availability in organic soils. They concluded that the ideal $\mathrm{pH}$ range (in terms of total nutrient availability) for wood-sedge soils to be between 5.5 and 5.8 and 5.0 for sphagnum peat soils. They further commented that this range is one to 1.5 points lower than what was considered ideal for mineral soils. This report formed the basis for future studies years later as the greenhouse industry switched from mineral soils to those composed primarily of peat or bark. Peterson (1980) documented the effect of substrate $\mathrm{pH}$ on macronutrient and micronutrient availability in a well-fertilized commercial greenhouse substrate (peat moss, perlite, vermiculite, granite sand, and composted pine bark; ratios not given). His study agreed with Lucas and Davis (1961) in that the optimum $\mathrm{pH}$ range was 5.2 to 5.5 , which he characterized as being a whole $\mathrm{pH}$ unit or more below what is considered optimum for mineral soils. Peterson (1980) reported decreasing availability of $\mathrm{P}$, iron (Fe), man- ganese $(\mathrm{Mn})$, boron $(\mathrm{B})$, zinc $(\mathrm{Zn})$, and copper $(\mathrm{Cu})$ with increasing $\mathrm{pH}$. Argo (1998) reviewed the effects of $\mathrm{pH}$ on nutrient availability in soilless substrates citing numerous sources and generally agreed with conclusions from Peterson (1980).

In view of the widespread use of DFB in the Pacific Northwest, and the corresponding lack of information available on its chemical properties, two experiments were initiated to document the influence of $\mathrm{pH}$ on nutrient availability. The objectives of these experiments were to determine the influence of two lime sources on DFB pH as well as nutrient availability with respect to changes in substrate $\mathrm{pH}$.

\section{Materials and Methods}

Expt. 1. On 20 June 2006, pH of 13 batches of DFB (each $0.03 \mathrm{~m}^{3}$ ) was adjusted using 13 rates of either calcium carbonate $\left(\mathrm{CaCO}_{3}\right.$; Imperial Limestone; J.A. Jack and Sons, Seattle, WA) or hydrated lime [calcium hydroxide, $\mathrm{Ca}(\mathrm{OH})_{2}$ ]; Kemilime; Ash Grove Cement Co, Portland, OR] (Table 1). A nonamended control (no lime) was also included. Rates for each lime type were selected to provide substrates with a spectrum of low to high $\mathrm{pH}$ and were based on previous research by the authors (unpublished data). Calcium carbonate $\left[97 \% \mathrm{CaCO}_{3}, 2 \% \mathrm{MgCO}_{3}, 97\right.$ calcium carbonate equivalency (CCE)] was processed such that $100 \%$ and $80 \%$ passed through 40 and 100 mesh, respectively. Hydrated lime $\left[94 \% \mathrm{Ca}(\mathrm{OH})_{2}, 126 \mathrm{CCE}\right]$ was processed such that $100 \%$ and $99 \%$ passed through 40 and 100 mesh, respectively. Bark was ground with a hammer-mill, passed through a 2.2-cm screen, and aged for $\approx 6$ months (Marr Bros. Co., Monmouth, OR). Eight No. 1 containers $(2.8$ L) were filled with each bark batch and maintained in a retractable roof greenhouse (Cravo Equip. Ltd., Brantford, Ontario, Canada) in Aurora, OR. Containers were overhead-irrigated with groundwater at $1.2 \mathrm{~cm} \cdot \mathrm{d}^{-1}($ Table 2 ). Four containers of each treatment were randomly selected and harvested 1 and 6 weeks after potting (WAP) by placing the entire contents of the container into a plastic bag for delivery to the laboratory. Bark samples were analyzed for $\mathrm{pH}$, ammonium $\left(\mathrm{NH}_{4}-\mathrm{N}\right)$, nitrate $\left(\mathrm{NO}_{3}-\mathrm{N}\right), \mathrm{P}, \mathrm{K}, \mathrm{Ca}, \mathrm{Mg}$, and sulfate $\left(\mathrm{SO}_{4}{ }^{2-}\right)$ using the saturated media extract (SME) method with deionized water as the extractant (Gavlak et al., 2003; Warncke, 1998). Boron, Fe, Mn, Cu, Zn, and aluminum $(\mathrm{Al})$ were analyzed using a SME with diethylenetriaminepentaacetic acid (DTPA) as the extractant (Warncke, 1998). Following Gavlak et al. (2003), DFB was soaked in the extractant (either water or DTPA) for $24 \mathrm{~h}$. Ammonium and $\mathrm{NO}_{3}-\mathrm{N}$ in extracted solutions were analyzed colorimetrically using a Lachat Quick Chem 8000 (Lachat Instruments, Milwaukee, WI). All other elements were analyzed with inductively coupled plasma-emission spectrometry (Thermo Jarrel Ash, Offenbach, Germany). 
Table 1. Water and DTPA-extractable nutrients in Douglas fir bark after incorporation of two lime types with multiple rates. ${ }^{z}$

\begin{tabular}{|c|c|c|c|c|c|c|c|c|c|c|c|c|c|c|c|}
\hline \multirow{2}{*}{$\begin{array}{l}\text { Harvest time } \\
\text { (weeks) }\end{array}$} & \multirow{2}{*}{$\begin{array}{l}\text { Lime } \\
\text { type }\end{array}$} & \multirow{2}{*}{$\begin{array}{c}\text { Rate } \\
\left(\mathrm{kg} \cdot \mathrm{m}^{-3}\right)\end{array}$} & \multicolumn{7}{|c|}{ Water extraction ${ }^{y}$} & \multicolumn{6}{|c|}{ DTPA extraction } \\
\hline & & & $\overline{\mathrm{pH}}$ & $\mathrm{P}$ & $\mathrm{K}$ & $\mathrm{Ca}$ & $\mathrm{Mg}$ & $\mathrm{SO}_{4}^{2-}$ & $\mathrm{Na}$ & B & $\mathrm{Fe}$ & $\mathrm{Mn}$ & $\mathrm{Cu}$ & $\mathrm{Zn}$ & $\mathrm{Al}$ \\
\hline \multirow[t]{14}{*}{$\overline{1}$} & - & 0 & 4.9 & 5.5 & 17.8 & 2.6 & 1.2 & 5.3 & 6.1 & 0.30 & 54.8 & 10.6 & 0.40 & 2.4 & 22.9 \\
\hline & $\mathrm{CaCO}_{3}$ & 0.6 & 5.4 & 7.1 & 24.9 & 5.8 & 1.7 & 5.4 & 6.7 & 0.28 & 50.3 & 13.5 & 0.37 & 2.4 & 18.1 \\
\hline & & 1.5 & 6.1 & 5.8 & 27.2 & 8.5 & 1.9 & 5.3 & 7.0 & 0.23 & 44.0 & 14.9 & 0.33 & 2.4 & 12.5 \\
\hline & & 3.0 & 6.5 & 4.5 & 27.5 & 11.9 & 2.2 & 5.2 & 7.1 & 0.16 & 31.8 & 15.8 & 0.28 & 2.4 & 5.5 \\
\hline & & 4.4 & 6.8 & 5.2 & 28.5 & 15.0 & 2.5 & 4.5 & 6.6 & 0.12 & 20.3 & 15.3 & 0.23 & 2.2 & 1.8 \\
\hline & & 5.9 & 6.9 & 5.0 & 29.1 & 18.3 & 2.8 & 4.7 & 6.4 & 0.10 & 13.0 & 13.6 & 0.20 & 1.9 & 1.4 \\
\hline & & 8.9 & 7.0 & 5.4 & 27.7 & 18.4 & 2.8 & 4.6 & 6.4 & 0.11 & 14.0 & 14.3 & 0.22 & 2.0 & 1.4 \\
\hline & & 11.9 & 6.9 & 4.2 & 21.6 & 15.0 & 2.4 & 5.6 & 7.6 & 0.10 & 9.9 & 13.1 & 0.20 & 1.9 & 1.3 \\
\hline & $\mathrm{Ca}(\mathrm{OH})_{2}$ & 4.4 & 7.2 & 3.0 & 17.4 & 18.8 & 2.0 & 6.2 & 8.2 & 0.09 & 7.3 & 12.6 & 0.22 & 1.9 & 1.0 \\
\hline & & 5.9 & 7.4 & 4.6 & 37.0 & 43.2 & 3.7 & 9.1 & 10.2 & 0.08 & 4.3 & 13.6 & 0.21 & 2.0 & 0.8 \\
\hline & & 8.9 & 7.9 & 2.3 & 42.8 & 73.6 & 4.8 & 10.0 & 11.2 & 0.07 & 1.7 & 13.5 & 0.20 & 2.1 & 0.9 \\
\hline & & 11.9 & 7.8 & 2.1 & 57.4 & 112.2 & 6.5 & 9.8 & 9.2 & 0.08 & 1.0 & 15.6 & 0.22 & 2.6 & 0.9 \\
\hline & & 17.8 & 7.9 & 1.8 & 84.7 & 240.2 & 11.8 & 12.7 & 10.3 & 0.06 & 0.8 & 14.6 & 0.23 & 2.6 & 0.7 \\
\hline & & 23.7 & 8.8 & 1.2 & 84.2 & 293.4 & 9.5 & 16.0 & 11.5 & 0.05 & 0.3 & 10.5 & 0.17 & 2.2 & 0.7 \\
\hline \multirow[t]{14}{*}{6} & - & 0.0 & 6.0 & 1.6 & 4.3 & 1.8 & 0.7 & 6.5 & 7.9 & 0.15 & 40.8 & 14.6 & 0.35 & 2.5 & 10.2 \\
\hline & $\mathrm{CaCO}_{3}$ & 0.6 & 6.2 & 2.5 & 6.1 & 1.1 & 0.5 & 7.2 & 9.7 & 0.16 & 37.7 & 14.9 & 0.32 & 2.3 & 9.5 \\
\hline & & 1.5 & 6.7 & 2.0 & 5.7 & 2.2 & 0.8 & 6.0 & 9.4 & 0.13 & 30.4 & 15.6 & 0.28 & 2.3 & 5.6 \\
\hline & & 3.0 & 7.2 & 2.1 & 6.6 & 3.9 & 1.1 & 10.2 & 9.7 & 0.10 & 21.0 & 14.3 & 0.23 & 2.0 & 3.0 \\
\hline & & 4.4 & 7.4 & 2.4 & 8.0 & 5.3 & 1.2 & 8.9 & 10.9 & 0.07 & 15.9 & 14.7 & 0.22 & 2.0 & 1.7 \\
\hline & & 5.9 & 7.5 & 2.0 & 6.2 & 4.4 & 1.1 & 6.7 & 11.9 & 0.06 & 11.3 & 15.6 & 0.21 & 2.1 & 1.0 \\
\hline & & 8.9 & 7.7 & 1.6 & 4.9 & 3.6 & 0.9 & 6.7 & 12.5 & 0.05 & 7.1 & 14.9 & 0.20 & 2.0 & 0.7 \\
\hline & & 11.9 & 7.7 & 2.0 & 7.4 & 8.9 & 1.6 & 7.0 & 12.0 & 0.05 & 6.2 & 14.4 & 0.18 & 1.9 & 0.6 \\
\hline & $\mathrm{Ca}(\mathrm{OH})_{2}$ & 4.4 & 7.7 & 4.1 & 10.9 & 14.7 & 2.2 & 6.6 & 9.5 & 0.07 & 15.4 & 16.1 & 0.24 & 2.2 & 1.3 \\
\hline & & 5.9 & 7.8 & 3.4 & 7.5 & 22.2 & 2.6 & 7.8 & 11.1 & 0.05 & 10.1 & 15.7 & 0.23 & 2.3 & 0.8 \\
\hline & & 8.9 & 8.0 & 1.9 & 6.3 & 32.9 & 2.8 & 7.0 & 10.1 & 0.04 & 2.5 & 12.6 & 0.18 & 2.0 & 0.5 \\
\hline & & 11.9 & 8.2 & 1.0 & 7.5 & 30.7 & 2.5 & 7.6 & 10.7 & 0.05 & 1.4 & 10.7 & 0.17 & 1.7 & 0.6 \\
\hline & & 17.8 & 8.4 & 0.7 & 10.6 & 60.9 & 4.3 & 8.0 & 11.0 & 0.04 & 1.0 & 8.0 & 0.14 & 1.4 & 0.5 \\
\hline & & 23.7 & 8.5 & 0.6 & 16.1 & 72.4 & 4.6 & 9.3 & 11.0 & 0.04 & 0.8 & 7.0 & 0.13 & 1.2 & 0.6 \\
\hline \multicolumn{16}{|l|}{ Main effects } \\
\hline \multicolumn{3}{|c|}{ Lime type (L) } & & 0.0001 & 0.0001 & 0.0001 & 0.0001 & 0.0001 & 0.0001 & 0.0001 & 0.0001 & 0.0001 & 0.0001 & 0.0001 & 0.0001 \\
\hline \multicolumn{3}{|c|}{ Lime rate (lime type) $\mathrm{R}(\mathrm{L})$} & & 0.0001 & 0.0001 & 0.0001 & 0.0001 & 0.0001 & 0.1931 & 0.0001 & 0.0001 & 0.0001 & 0.0001 & 0.0001 & 0.0001 \\
\hline \multicolumn{3}{|c|}{ Harvest time $(\mathrm{T})$} & & 0.0001 & 0.0001 & 0.0001 & 0.0001 & 0.7090 & 0.0001 & 0.0001 & 0.0001 & 0.0801 & 0.0001 & 0.0001 & 0.0001 \\
\hline \multicolumn{3}{|l|}{$\mathrm{T}^{*} \mathrm{~L}$} & & 0.0001 & 0.0001 & 0.0001 & 0.0001 & 0.0001 & 0.0001 & 0.0001 & 0.0001 & 0.0001 & 0.4045 & 0.0001 & 0.0001 \\
\hline \multicolumn{3}{|l|}{$\mathrm{T}^{*} \mathrm{R}(\mathrm{L})$} & & 0.0003 & 0.0001 & 0.0001 & 0.0001 & 0.0017 & 0.0062 & 0.0001 & 0.0001 & 0.0001 & 0.0001 & 0.0001 & 0.0001 \\
\hline
\end{tabular}

${ }^{\mathrm{z}}$ Extractions performed 1 and 6 weeks after potting (WAP). Containers subjected to typical nursery irrigation $\left(1 \cdot 2 \mathrm{~cm} \cdot \mathrm{d}^{-1}\right)$.

${ }^{\mathrm{y}}$ Water and 0.005 M DTPA (diethylenetriaminepentaacetic acid) extractions were conducted over $24 \mathrm{~h}$.

Table 2. Chemical characteristics of groundwater used for irrigation at the Oregon State University North Willamette Research and Extension Center.

\begin{tabular}{lc}
\hline $\mathrm{pH}$ & 7.0 \\
Alkalinity & $87.3 \mathrm{mg} \cdot \mathrm{L}^{-1}$ \\
Hardness & $86.8 \mathrm{mg} \cdot \mathrm{L}^{-1}$ \\
Total dissolved solids & $129.5 \mathrm{mg} \cdot \mathrm{L}^{-1}$ \\
Electrical conductivity & $0.2 \mathrm{dS} \cdot \mathrm{m}$ \\
Sodium & $6.9 \mathrm{mg} \cdot \mathrm{L}^{-1}$ \\
Chloride & $1.5 \mathrm{mg} \cdot \mathrm{L}^{-1}$ \\
Potassium & $2.1 \mathrm{mg} \cdot \mathrm{L}^{-1}$ \\
Calcium & $19.8 \mathrm{mg} \cdot \mathrm{L}^{-1}$ \\
Magnesium & $8.9 \mathrm{mg} \cdot \mathrm{L}^{-1}$ \\
Sulfate & $12.9 \mathrm{mg} \cdot \mathrm{L}^{-1}$ \\
Iron & $0.3 \mathrm{mg} \cdot \mathrm{L}^{-1}$ \\
Manganese & $0.1 \mathrm{mg} \cdot \mathrm{L}^{-1}$ \\
Boron & $0.0 \mathrm{mg} \cdot \mathrm{L}^{-1}$ \\
Copper & $0.0 \mathrm{mg} \cdot \mathrm{L}^{-1}$ \\
Zinc & $0.1 \mathrm{mg} \cdot \mathrm{L}^{-1}$ \\
Aluminum & $0.2 \mathrm{mg} \cdot \mathrm{L}^{-1}$ \\
\hline
\end{tabular}

Expt. 2. On 8 Aug. 2006, a second repetition of the experiment was conducted similarly to the previous one. Data from both experiments were analyzed with repeated measures analysis of variance to determine significant main effects (Table 1). Nonlinear regression was used to determine the most appropriate model for $\mathrm{pH}$ response to lime rate as well as nutrient availability response to substrate $\mathrm{pH}$. Procedures described by
Schabenberger and Pierce (2002) were used for nonlinear model selection and comparison. All statistical analyses were conducted with SAS 9.1 (SAS Institute, Cary, NC), although figures were constructed with SigmaPlot 10.0 (Systat Software, San Jose, CA).

\section{Results and Discussion}

Results from the two repetitions of the experiment were similar; thus, data were pooled in Table 1 and presented together in Figures 1 through 3 . As a result of lime amendment, substrate $\mathrm{pH}$ ranged from 4.8 to 9.4 across both experiments (Figs. 2 and 3 ). Substrate $\mathrm{pH}$ increased exponentially with increasing $\mathrm{CaCO}_{3}$ rate (Figs. 1A and $1 \mathrm{C}$ ). Williams et al. (1988) reported that $\mathrm{pH}$ of sphagnum peat increases quadratically with increasing lime rates up to $7 \mathrm{~kg} \cdot \mathrm{m}^{-3}$. However, use of quadratic functions implies that $\mathrm{pH}$ would decline with increasing lime rate at some point beyond the observed range, which is unlikely. Exponential curves $[\mathrm{pH}=\mathrm{c}+$ $\mathrm{a}\left(1-\mathrm{b}^{\mathrm{x}}\right)$ ] provide a more realistic fit to the data in that $\mathrm{pH}$ increases rapidly but then plateaus at some maximum value. Furthermore, parameter estimates of the exponential equation provide intuitive interpretation in that the solved estimate for $\mathrm{c}$ is $\mathrm{pH}$ of the substrate with $0 \mathrm{~kg} \cdot \mathrm{m}^{-3}$ (or nonamended $\mathrm{pH}$ ), the sum of $\mathrm{c}$ and $\mathrm{a}$ is equal to the maximum $\mathrm{pH}$ (or the point where the curve plateaus), and $b$ (greater than 0 ) is a gauge of how rapidly $\mathrm{pH}$ increases from its minimum to maximum (steepness of the curve). Williams et al. (1988) suggest that as exchange sites become saturated with $\mathrm{Ca}^{2+}$ and $\mathrm{Mg}^{2+}$ ions, an increasing number of these ions were needed to further dissociate $\mathrm{H}^{+}$into the substrate solution. This is a logical explanation considering the exponential relationship between lime rate and substrate $\mathrm{pH}$. Substrate $\mathrm{pH}$ also increased exponentially with increasing $\mathrm{Ca}(\mathrm{OH})_{2}$ rate (Figs. $1 \mathrm{~B}$ and $\left.1 \mathrm{D}\right)$.

Within a lime treatment, substrate $\mathrm{pH}$ increased from 1 to 6 WAP (Table 1). Across both lime types and experiments, adding more than 3 to $6 \mathrm{~kg} \cdot \mathrm{m}^{-3}$ lime had little or no effect on substrate $\mathrm{pH}$. Williams et al. (1988) reported slightly higher dolomitic lime rates were necessary to maximize $\mathrm{pH}$ in peat substrates.

Macronutrients. Extractable $\mathrm{NH}_{4}-\mathrm{N}$ and $\mathrm{NO}_{3}-\mathrm{N}$ levels were low throughout the study regardless of lime treatment and did not respond to substrate $\mathrm{pH}$ (data not presented). Douglas fir bark contains very little N. Bollen (1969) documented the C:N ratio of DFB as $491: 1$ with only $0.11 \%$ total $\mathrm{N}$ on a dry weight basis. Others have documented the influence of substrate $\mathrm{pH}$ on $\mathrm{N}$ form (Niemiera and Wright, 1986; Ogden et al., 1987) 

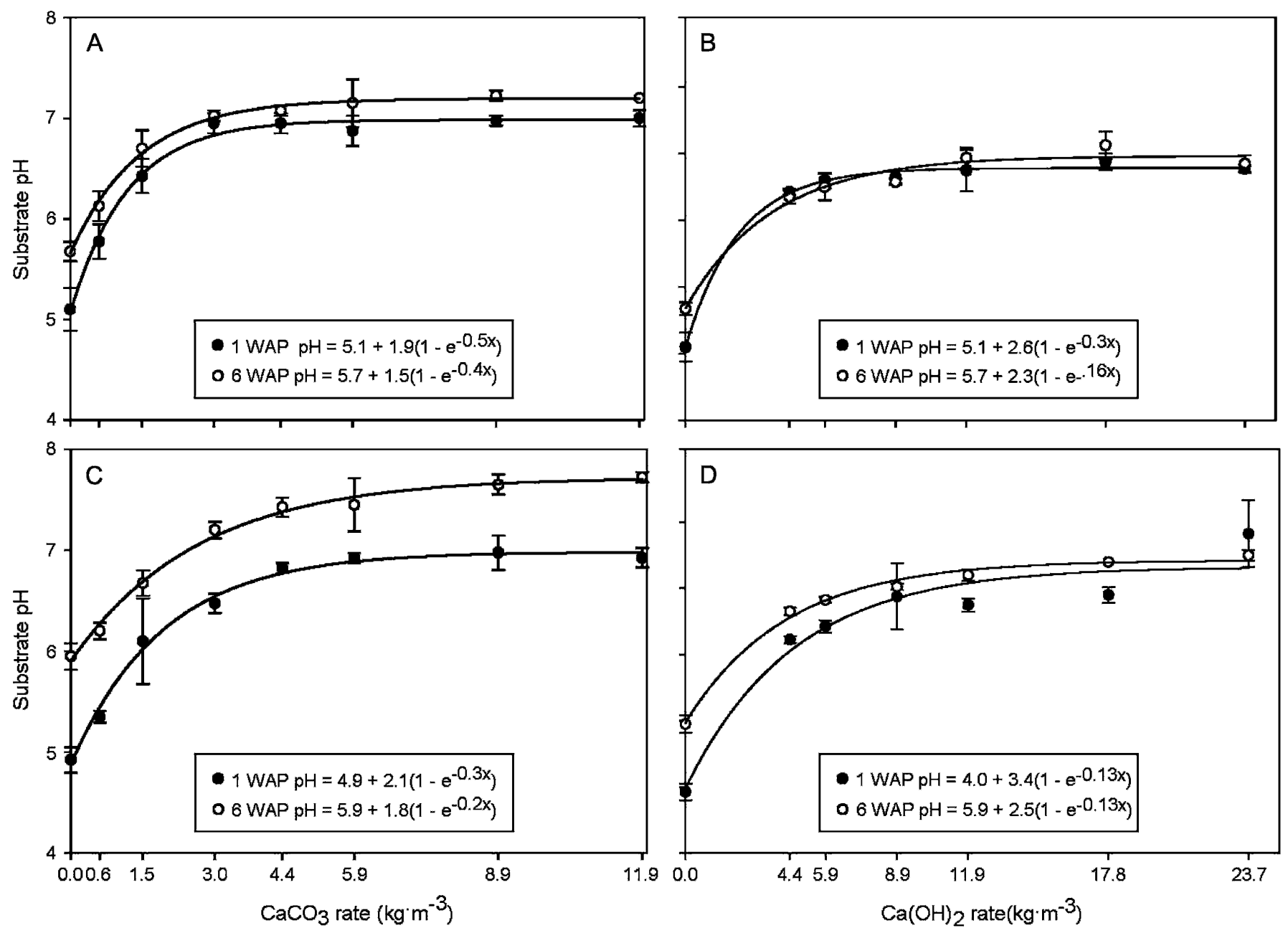

Fig. 1. Douglas fir bark $\mathrm{pH}$ response to $\mathrm{CaCO}_{3}$ and $\mathrm{Ca}(\mathrm{OH})_{2}$ rates and 1 and 6 weeks after potting (WAP) in two experiments conducted in June (A and $\left.\mathbf{B}\right)$ and Aug. (C and D) 2006.

in well-fertilized containers. However, considering low $\mathrm{N}$ levels inherent in DFB, it is not surprising that $\mathrm{N}$ in nonfertilized DFB substrate did not respond to $\mathrm{pH}$.

Water-extractable $\mathrm{P}$ decreased with increasing $\mathrm{pH}$ at all collection dates (Fig. 2A). Lucas and Davis (1961) explained that P availability in an organic soil (greater than $50 \%$ organic matter) drops when $\mathrm{pH}$ is below 5.5 as a result of increased availability of $\mathrm{Fe}$ and $\mathrm{Al}$, which form precipitates with soluble P. Our data show no such decrease in availability below pH 5.5. Bunt (1988) suggests differences in $\mathrm{P}$ uptake by plants results from changes in the form of water-soluble $\mathrm{P}$ from $\mathrm{H}_{2} \mathrm{PO}_{4}{ }^{-}$to $\mathrm{HPO}_{4}{ }^{2-}$, the former being 10 times more available for plant uptake than the latter. Argo and Biernbaum (1996) report the equilibrium constant between these two phosphate forms is 7.2, so that when substrate $\mathrm{pH}$ is greater than 7.2, the less available $\mathrm{HPO}_{4}{ }^{2-}$ predominates and plant-available $\mathrm{P}$ is greatly reduced. Argo and Biernbaum (1996) further demonstrate that when substrate $\mathrm{pH}$ is less than 7.2 , plant $\mathrm{P}$ level is relatively unaffected regardless of the measurable decrease in water-extractable $\mathrm{P}$ with increasing $\mathrm{pH}$. Our data show that total water-extractable $\mathrm{P}$ decreased (without in- creasing) over the substrate $\mathrm{pH}$ range of 4.8 to 9.4 , although our analytical methods do not distinguish between the two species of watersoluble $\mathrm{P}, \mathrm{H}_{2} \mathrm{PO}_{4}^{-}$, and $\mathrm{HPO}_{4}^{2-}$. Peterson (1980) showed a similar trend to ours with his analysis of the effect of substrate $\mathrm{pH}$ on a peat-based mix.

Buamscha et al. (2007b) reported 10 to $28 \mathrm{mg} \cdot \mathrm{L}^{-1} \mathrm{P}$ in nonamended DFB analyzed immediately after collection from bark suppliers. However, by 1 WAP, waterextractable $\mathrm{P}$ in this experiment rarely exceeded $10 \mathrm{mg} \cdot \mathrm{L}^{-1}$. Within a given lime treatment, water-extractable $\mathrm{P}$ decreased from 1 to 6 WAP $(P=0.0001)$. Warncke (1998) suggests that 3 to $5 \mathrm{mg} \cdot \mathrm{L}^{-1} \mathrm{P}$ is sufficient for growth of most container crops using the SME procedure. Although extractable $\mathrm{P}$ is initially high in DFB, it is quickly leached from the substrate. Yeager and Wright (1982) reported similarly high levels of $\mathrm{P}$ in pine bark, but $67 \%$ of that $\mathrm{P}$ was leached after one simulated irrigation event.

Water-extractable $\mathrm{K}$ did not respond to substrate pH (Fig. 2B). By 6 WAP, levels of water-extractable $\mathrm{K}$ were low regardless of substrate $\mathrm{pH}$ compared with the recommendation by Warncke (1998) (60 to 149 $\left.\mathrm{mg} \cdot \mathrm{L}^{-1}\right)$. Lucas and Davis (1961) reported similar findings on organic peat soils in Michigan, but warns that conditions of high $\mathrm{Ca}$ (as would be typical if high lime rates are used) will competitively suppress uptake of K. Peterson (1980) showed no effect of $\mathrm{pH}$ on a well-fertilized greenhouse substrate. Buamscha et al. (2007b) reported 79 to $162 \mathrm{mg} \cdot \mathrm{L}^{-1} \mathrm{~K}$ in a nonamended DFB. By 1 WAP, waterextractable $\mathrm{K}$ levels averaged just $39 \mathrm{mg} \cdot \mathrm{L}^{-1}$ across lime rates and $15 \mathrm{mg} \cdot \mathrm{L}^{-1}$ by 6 WAP (Table 1). Potassium is readily leached from containers (Broschat, 1995); thus, leaching is likely the cause of progressively lower amounts of extractable $\mathrm{K}$ over time. Waterextractable $\mathrm{K}$ increased with increasing $\mathrm{Ca}(\mathrm{OH})_{2}$ rates, but this is more likely the result of dislodging of $\mathrm{K}$ from cation exchange sites with increasing levels of soluble $\mathrm{Ca}$.

Secondary nutrients. Levels of waterextractable $\mathrm{Ca}$ were more a function of $\mathrm{Ca}$ solubility of the lime products than of substrate $\mathrm{pH}$. Within each harvest date, waterextractable $\mathrm{Ca}$ increased moderately with increasing $\mathrm{CaCO}_{3}$ rates but increased more rapidly with increasing $\mathrm{Ca}(\mathrm{OH})_{2}$ rates (Table 1). Higher $\mathrm{Ca}$ levels would be expected from $\mathrm{Ca}(\mathrm{OH})_{2}$ amendments than $\mathrm{CaCO}_{3}$ as a result of solubility and the percent $\mathrm{Ca}$ content of each product. Calcium hydroxide has a 

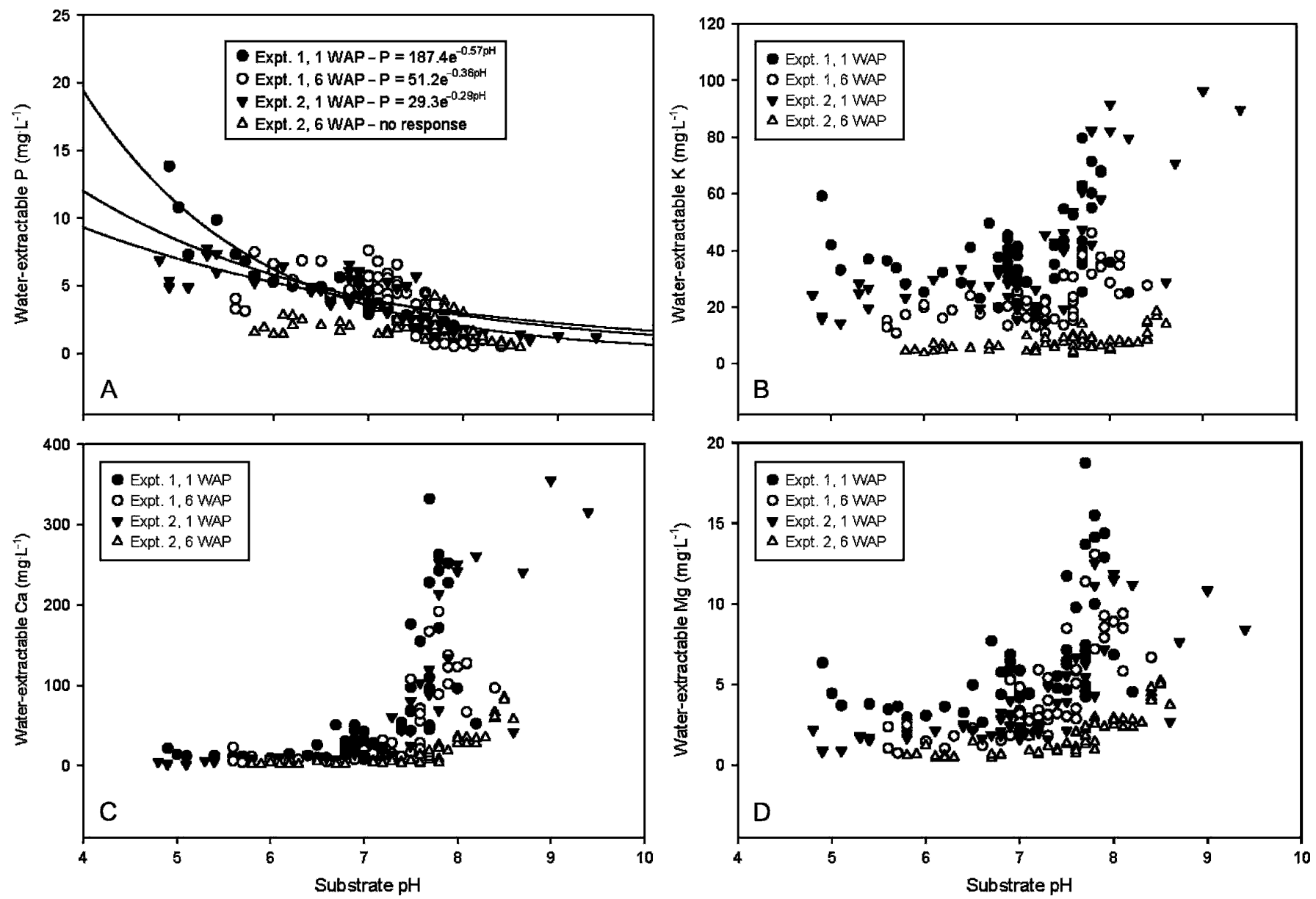

Fig. 2. Water-extractable phosphorus $(\mathrm{P})$, potassium $(\mathrm{K})$, calcium $(\mathrm{Ca})$, and magnesium $(\mathrm{Mg})$ in Douglas fir bark using the saturated extraction method. Extractions were performed 1 and 6 weeks after potting (WAP) in two separate experiments. Containers were subjected to typical nursery irrigation $\left(1.2 \mathrm{~cm} \cdot \mathrm{d}^{-1}\right)$ throughout experiments.

solubility product of $K_{\mathrm{sp}}=4.68 \times 10^{-6}$, whereas that for calcium carbonate is $K_{\mathrm{sp}}=$ $8.7 \times 10^{-9}$ (Lide, 2007), indicating over a thousand-fold difference in solubility. Furthermore, $\mathrm{CaCO}_{3}$ is $\approx 37 \% \mathrm{Ca}$, whereas $\mathrm{Ca}(\mathrm{OH})_{2}$ is $\approx 67 \% \mathrm{Ca}$. Argo (1998) argued that low $\mathrm{pH}$ does not reduce $\mathrm{Ca}$ availability, but instead low $\mathrm{pH}$ is the result of insufficient $\mathrm{Ca}$ sources (lime or high-alkalinity water) applied to the substrate. Our data tend to support this notion in that $\mathrm{Ca}$ availability is a function of lime type and rate and not a function of $\mathrm{pH}$.

Similar to $\mathrm{Ca}$, water-extractable $\mathrm{Mg}$ increased with increasing $\mathrm{pH}$ but was more likely a function of increasing lime rate (Figs. $2 \mathrm{C}$ and 2D). Although both lime sources were Ca-based, both had low levels of $\mathrm{Mg}$ contamination (less than 2\%). It is also possible that $\mathrm{Ca}-\mathrm{Mg}$ competition for cation exchange sites caused an increase in extractable $\mathrm{Mg}$ at higher rates of $\mathrm{Ca}(\mathrm{OH})_{2}$. Peterson (1980) reported that $\mathrm{Mg}$ increased with increasing $\mathrm{pH}$, in which $\mathrm{pH}$ was similarly adjusted with $\mathrm{Ca}(\mathrm{OH})_{2}$ amendment.

Sulfate levels were affected by lime type and rate (Table 1); however, the differences in water-extractable sulfate levels across lime types and rates were minor (less than 5 $\mathrm{mg} \cdot \mathrm{L}^{-1}$ ) by 6 WAP. Sulfate anions are easily leached from container substrates (Yeager and Barrett, 1985). Nonetheless, sulfate levels did not decrease between 1 and 6 WAP $(P=0.709)$, and they were similar to levels reported by Buamscha (2007b) for nonamended and nonirrigated DFB (10 to 20 $\left.\mathrm{mg} \cdot \mathrm{L}^{-1}\right)$. Browder (2004) concluded that 7 to $15 \mathrm{mg} \cdot \mathrm{L}^{-1}$ sulfate (as measured in a pourthrough procedure) should be present for optimum growth of pin oak (Quercus palustris Münchh) and japanese maple (Acer palmatum Thunb.). Handreck (1986) states that $6 \mathrm{mg} \cdot \mathrm{L}^{-1}$ sulfate from a water extraction is sufficient for any crop. By this standard, sulfate levels are low to marginally sufficient. However, this is of little consequence because sulfate is provided in many fertilizer types such as ammonium sulfate $\left[\left(\mathrm{NH}_{4}\right)_{2} \mathrm{SO}_{4}\right]$ used in controlled-release fertilizers, gypsum $\left(\mathrm{CaSO}_{4}\right)$, and sulfated micronutrients.

Micronutrients. Several studies have documented the micronutrient capacity of soilless substrates, each suggesting that the substrate alone may be a sufficient source of micronutrients to meet plant need without addition of supplemental micronutrient fertilizers (Buamscha et al., 2007a; Niemiera, 1992; Rose and Wang, 1999). Availability of micronutrients has been documented as $\mathrm{pH}$-sensitive in organic soils and substrates
(Lucas and Davis, 1961; Peterson, 1980); thus, the degree to which a substrate can provide sufficient micronutrients to support crop growth should always be qualified with a target $\mathrm{pH}$ range.

DTPA-extractable B decreased exponentially with increasing substrate $\mathrm{pH}$ (Fig. 3A). Extractable B decreased slightly from 1 to 6 WAP; however, the relationship between substrate $\mathrm{pH}$ and extractable $\mathrm{B}$ remained consistent across experiments and harvest dates. Lucas and Davis (1961) warn that there is a strong $\mathrm{Ca}-\mathrm{B}$ relationship in organic soils, and some peat soils high in $\mathrm{Ca}$ are more prone to $\mathrm{B}$ deficiency as a result of elevated $\mathrm{Ca}$. In DFB, the relationship between DTPAextractable $\mathrm{B}$ and $\mathrm{pH}$ is more consistent and predictable than the relationship between DTPA-extractable B and water-extractable Ca (data not shown). Warncke (1998) suggests DTPA-extractable $B$ should range from 0.7 to $2.5 \mathrm{mg} \cdot \mathrm{L}^{-1}$; thus, extractable $\mathrm{B}$ would be considered low in nonamended DFB. Buamscha et al. (2007a) demonstrated that DFB, even amended with a micronutrient fertilizer package (Micromax; The Scotts Co., Marysville, $\mathrm{OH}$ ), had lower than recommended extractable B levels 5 and 8 WAP, but higher than recommended foliar B in annual vinca [Catharanthus roseus (L.) G. 

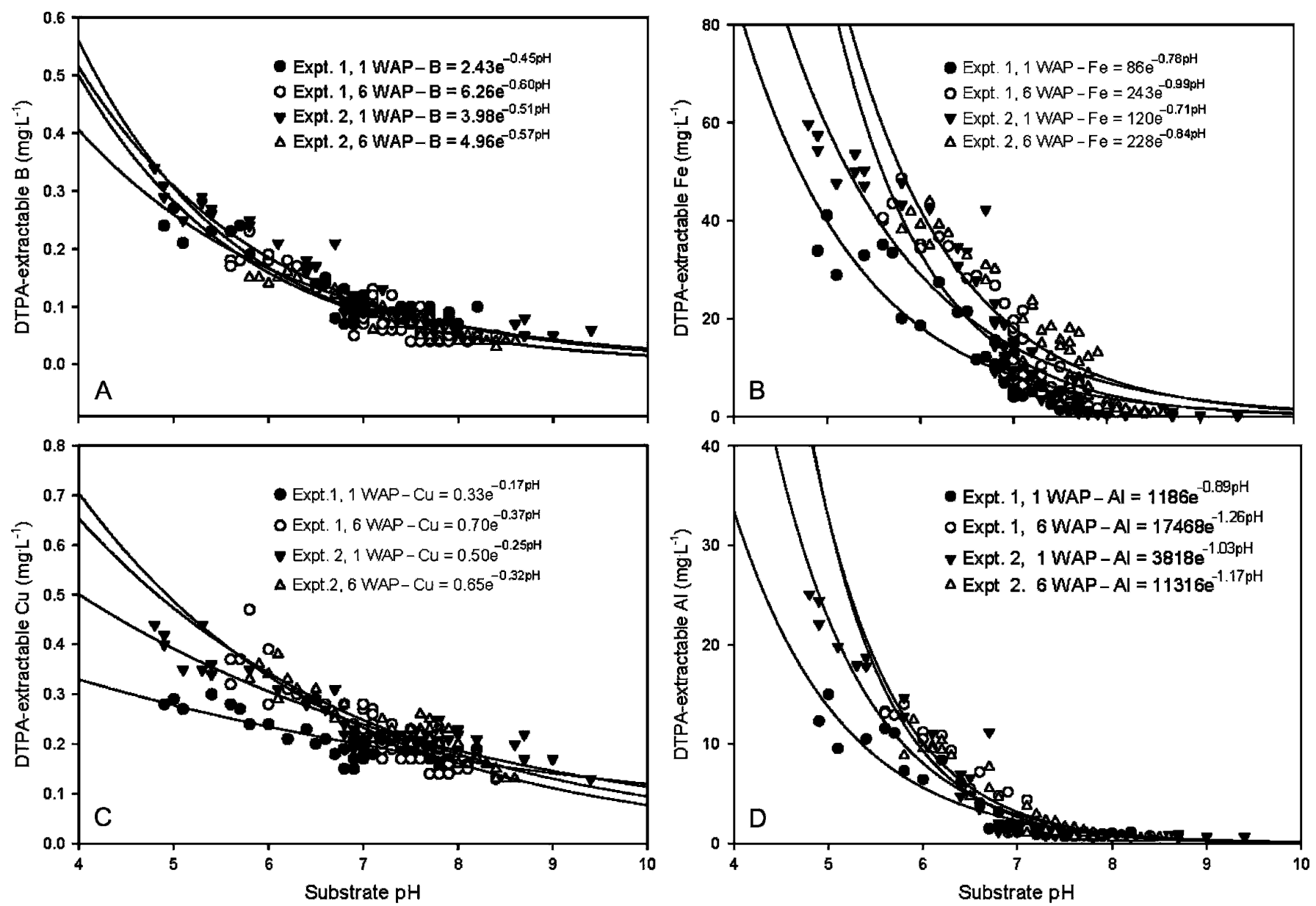

Fig. 3. Relationship between DTPA-extractable boron (B), iron (Fe), copper $(\mathrm{Cu})$, and aluminum $(\mathrm{Al})$ in Douglas fir bark using the saturated extraction method. Extractions were performed 1 and 6 weeks after potting (WAP) in two separate experiments. Containers were subjected to typical nursery irrigation $\left(1.2 \mathrm{~cm} \cdot \mathrm{d}^{-1}\right)$ throughout the experiment.

Don 'Peppermint Cooler']. The relationship between $\mathrm{B}$ requirements in plant foliage and substrate-extractable B requires further study to improve recommended sufficiency ranges.

DTPA-extractable Fe decreased exponentially with increasing substrate $\mathrm{pH}$ with $\mathrm{Fe}$ dropping below recommended levels at $\mathrm{pH}$ $\approx 7$ (Fig. 3B). Berghage et al. (1987) reported DTPA-extractable Fe decreased quadratically over the $\mathrm{pH}$ range of 3.5 to 7.5 . Despite different mathematical models used to describe our data and that of Berghage et al. (1987), Fe response to $\mathrm{pH}$ in the two studies appears to be similar. Substrate Fe levels should range from 15 to $40 \mathrm{mg} \cdot \mathrm{L}^{-1}$ (Warncke, 1998). Douglas fir bark has sufficient extractable Fe so long as $\mathrm{pH}$ is below 7. Lucas and Davis (1961) commented that Fe deficiency is rarely a problem in organic soils as a result of an abundance of humic acids maintaining Fe levels.

Neither Mn nor Zn responded to substrate pH (data not shown). Berghage et al. (1987) reported that DTPA-extractable Mn was slightly affected (not specific) and $\mathrm{Zn}$ was unaffected over a substrate $\mathrm{pH}$ range of 3.5 to 7.5 . Extractable Mn levels in all substrates were above the recommended range ( 5 to $30 \mathrm{mg} \cdot \mathrm{L}^{-1}$ ), whereas extractable $\mathrm{Zn}$ was below recommended levels (5 to $30 \mathrm{mg} \cdot \mathrm{L}^{-1}$ ). Buamscha et al. (2007a) demonstrated that fresh and aged DFB amended only with nitrogenphosphorus-potassium fertilizers provided sufficient $\mathrm{Zn}$ for annual vinca through 8 weeks of production despite low levels of DTPA-extractable $\mathrm{Zn}$ in the substrate.

DTPA-extractable $\mathrm{Cu}$ decreased exponentially with increasing substrate $\mathrm{pH}$ (Fig. 3C). Handreck (1994) reported DTPAextractable $\mathrm{Cu}$ in pine (Pinus radiata $\mathrm{D}$. Don) bark was unaffected by substrate $\mathrm{pH}$ over the range 4.5 to 6.5 . Either DFB differs substantially from pine bark evaluated by Handreck or the narrower range of $\mathrm{pH}$ observed in his study was insufficient to reveal a relationship. Handreck (1990) in a separate study reported that DTPA-extractable $\mathrm{Cu}$ in substrates should be greater than $0.25 \mathrm{mg} \cdot \mathrm{L}^{-1}$ to avoid deficiency symptoms in flowering mums (Chrysanthemum $\times$ morifolium Ramat. 'Yellow Mandalay'), but levels should be at least $5.1 \mathrm{mg} \cdot \mathrm{L}^{-1}$ to maximize plant growth.

Nonessential elements. Water-extractable $\mathrm{Na}$ did not respond to substrate $\mathrm{pH}$ (data not shown). Warncke (1998) recommends extractable $\mathrm{Na}$ levels in container substrates be less than $40 \mathrm{mg} \cdot \mathrm{L}^{-1}$. After 6 weeks of irrigation, water-extractable $\mathrm{Na}$ ranged from 3 to $15 \mathrm{mg} \cdot \mathrm{L}^{-1}$ across both experiments with levels increasing slightly from 1 to 6 WAP. Increased $\mathrm{Na}$ levels over time were likely the result of accumulation from low levels of $\mathrm{Na}$ in irrigation water (Table 2).

Extractable Al in substrates is rarely considered. This is possibly the result of the general agreement that organic soils and soilless media contain low amounts of $\mathrm{Al}$ (Lucas and Davis, 1961; Yeager and Barrett, 1985). Significant amounts of $\mathrm{Al}$ ( 7.8 to 51.5 $\mathrm{mg} \cdot \mathrm{L}^{-1}$ ) were extracted from DFB in samples collected from bark suppliers (before amendment or irrigation in a nursery) (Buamscha et al., 2007b). DTPA-extractable Al decreased exponentially with increasing $\mathrm{pH}$ (Fig. 3D). Aluminum levels averaged 23.9 $\mathrm{mg} \cdot \mathrm{L}^{-1}$ in nonamended bark 1 WAP (Table 1), although levels decreased over time. Wright (1989) reviewed Al interactions with soils and crops, and described $\mathrm{Al}$ speciation as complex, dependent on soil $\mathrm{pH}$ and other mineralogical factors and difficult to predict. Wright (1989) also explains that Al forms complex ligands with sulfate and soluble organic compounds, which alleviate Al toxicity. In contrast to the notion that $\mathrm{Al}$ is lacking or only present in low concentration in bark substrates, it is likely that it is present in relatively high levels (pH-dependent) but in nontoxic forms as a result of a consistent 
supply of sulfate from bark (Table 1) and fertilizer amendments as well as the presence of soluble organic compounds in DFB. It is unclear what levels of DTPA-extractable Al should be considered toxic in nursery substrates.

Water-extractable P and DTPA-extractable $\mathrm{B}, \mathrm{Fe}, \mathrm{Cu}$, and $\mathrm{Al}$ are responsive to $\mathrm{pH}$ in nonamended DFB. Other nutrients were either nonresponsive to substrate $\mathrm{pH}$ or the observed response was deemed more likely caused by Ca competition on cation exchange sites. Although $\mathrm{Ca}$ and its competitive effects on cation exchange sites may be an undesirable artifact in a study such as this, applications of lime (and thus $\mathrm{Ca}$ ) is the primary mechanism by which nursery growers adjust substrate $\mathrm{pH}$. Irrigation water alkalinity (dissolved $\mathrm{CO}_{3}{ }^{2-}$ and $\mathrm{HCO}_{3}^{-}$) is another major factor affecting substrate $\mathrm{pH}$, but across three sampling dates, $\mathrm{Ca}$ and alkalinity levels in Oregon nursery irrigation sources were highly correlated $(\mathrm{r}=0.80, \mathrm{n}=61$, unpublished data).

These results have several practical implications. Phosphorus levels across all lime treatments declined from 1 to 6 WAP, suggesting that DFB alone is not a sufficient source of $\mathrm{P}$ to sustain plant growth throughout a growing season. However, the common industry practice of incorporating a watersoluble source of $P$ into the substrate as a starter fertilizer should be questioned. There is sufficient water-extractable $\mathrm{P}$ in the first few weeks of production contingent that substrate $\mathrm{pH}$ is low (less than 6). Waterextractable $\mathrm{K}$ declined steadily over time regardless of $\mathrm{pH}$ and thus should be supplemented in some sort of continuous manner throughout the production cycle of the crop. Like $\mathrm{P}, \mathrm{K}$ is readily available from DFB soon after potting and thus its application in starter fertilizer packages is questionable. Calcium and $\mathrm{Mg}$ levels were dependent on lime rate. In typical nursery conditions, it would be difficult to appreciably raise substrate $\mathrm{pH}$ without the addition of calcium and magnesium carbonates (through lime application or irrigation water alkalinity). Sulfate levels were moderately low, but this is probably inconsequential considering the widespread use of sulfate-based fertilizers. Douglas fir bark has been reported to provide sufficient micronutrients for short-term container crops (Buamscha et al., 2007a); however, Buamscha warns that this observation may only be valid at low $\mathrm{pH}$ (less than 5.7). This warning is justified considering the $\mathrm{pH}$-dependent availability of $\mathrm{Fe}, \mathrm{B}$, and $\mathrm{Cu}$ in DFB.

Data herein provide a realistic model of how plant essential nutrients respond to substrate $\mathrm{pH}$ in DFB. These data suggest that even low lime rates have a profound effect on nutrient availability in DFB and that lime should be used in moderation. However, it is uncertain if substrate $\mathrm{pH}$ would similarly affect nutrient availability in substrates receiving supplemental fertilizers typical of nursery production. Future research will address the impact of lime additions and substrate $\mathrm{pH}$ on nutrient availability in wellfertilized DFB substrates.

\section{Literature Cited}

Altland, J.E. 2006. Substrate pH, a tricky topic. Digger 50:42-47.

Argo, W.R. 1998. Root medium chemical properties. HortTechnology 8:446-493.

Argo, W.R. and J.A. Biernbaum. 1996. The effect of lime, irrigation-water source, and watersoluble fertilizer on root-zone $\mathrm{pH}$, electrical conductivity, and macronutrient management of container root media with impatiens. J. Amer. Soc. Hort. Sci. 121:442-452.

Berghage, R.D., D.M. Krauskopf, D.D. Warncke, and I. Widders. 1987. Micronutrient testing of plant growth media: Extractant identification and evaluation. Commun. Soil Sci. Plant Anal. 18:1089-1109.

Bollen, W.B. 1969. Properties of tree barks in relation to their agricultural utilization. USDA For. Serv. Res. Paper PNW 77.

Broschat, T.K. 1995. Nitrate, phosphate, and potassium leaching from container-grown plants fertilized by several methods. HortScience 30:74-77.

Browder, J.F. 2004. Sulfur requirements of container-grown pin oak and Japanese maple. Va. Polytechnic Inst., Blacksburg, MS thesis.

Buamscha, M.G., J.E. Altland, D.M. Sullivan, and D.A. Horneck. 2007a. Micronutrient availability in fresh and aged Douglas fir bark. HortScience 42:152-156.

Buamscha, G.M., J.E. Altland, D.M. Sullivan, D.A. Horneck, and J. Cassidy. 2007b. Chemical and physical properties of Douglas fir bark relevant to the production of container plants. HortScience 42:1281-1286.

Bunt, A.C. 1988. Media and mixes for container grown plants. Allen and Unwin, Inc., Winchester, MA.

Gavlak, R., D. Horneck, R. Miller, and J. KotubyAmacher. 2003. Soil, plant, and water reference methods for the western region. 2nd Ed. WCC103 Publication, Fort Collins, CO.
Handreck, K.A. 1986. Critical concentrations of sulfur in liquid feeds for plants in containers. Scientia Hort. 30:1-17.

Handreck, K.A. 1990. Extractants for assessing the availability of copper to Chrysanthemum morifolium cultivar 'Yellow Mandalay' growing in soil-less media. Scientia Hort. 44:323-334.

Handreck, K.A. 1994. Effect of pH on the uptake of cadmium, copper, and zinc from soilless media containing sewage sludge. Commun. Soil Sci. Plant Anal. 25:1913-1927.

Lide D.R. (ed.). 2007. CRC handbook of chemistry and physics. Internet version 2007 (87th Ed.). Dec. 2007. <http:/www.hbcpnetbase.com>. Taylor and Francis, Boca Raton, FL.

Lucas, R.E. and J.F. Davis. 1961. Relationships between $\mathrm{pH}$ values of organic soils and availabilities of 12 plant nutrients. Soil Sci. 92:171-182.

Niemiera, A.X. 1992. Micronutrient supply from pine bark and micronutrient fertilizers. HortScience 27:272.

Niemiera, A.X. and R.D. Wright. 1986. Effect of liming rate on nitrification in a pine bark medium. J. Amer. Soc. Hort. Sci. 111:713-715.

Ogden, R.J., F.A. Pokorny, H.A. Mills, and M.G. Dunavent. 1987. Elemental status of pine barkbased potting media. Hort. Rev. (Amer. Soc. Hort. Sci.) 9:103-131.

Peterson, J.C. 1980. Effects of $\mathrm{pH}$ upon nutrient availability in a commercial soilless root medium utilized for floral crop production. Ohio Agr. Res. Dev. Ctr. Circ. 268:16-19.

Rose, M.A. and H. Wang. 1999. Comparison of micronutrient sources for container Rhododendron. HortTechnology 9:220-224.

Schabenberger, O. and F.J. Pierce. 2002. Contemporary statistical models for the plant and soil sciences. CRC Press, Boca Raton, FL.

Warncke, D. 1998. Recommended test procedure for greenhouse growth media, p. 34-37. In: Dahnke, W.C. (ed.). Recommended chemical soil test procedures for the north central region. North Central Reg. Res. Pub. No. 221. Miss. Agr. Expt. Stat. SB 1001.

Williams, B.J., J.C. Peterson, and J.D. Utzinger. 1988. Liming reaction in sphagnum peat-based growing media. J. Amer. Soc. Hort. Sci. 113:210-214.

Wright, R.D. and L.E. Hinsley. 1991. Growth of containerized eastern redcedar amended with dolomitic limestone and micronutrients. HortScience 26:143-145.

Wright, R.J. 1989. Soil aluminum toxicity and plant growth. Commun. Soil Sci. Plant Anal. 20:1479-1497.

Yeager, T.H. and J.E. Barrett. 1985. Phosphorous and sulfur leaching from an incubated superphosphate-amended soilless container medium. HortScience 20:671-672.

Yeager, T.H. and R.D. Wright. 1982. Pine barkphosphorus relationships. Commun. Soil Sci. Plant Anal. 13:57-66. 